\title{
Iridium(I) Pyridyl Azolate Complexes with Saturated Red Metal-to-Ligand Charge Transfer Phosphorescence; Fundamental and Potential Applications in Organic Light-Emitting Diodes
}

\section{Chung-Hong Fang, ${ }^{[a]}$ Yao-Lun Chen, ${ }^{[a]}$ Cheng-Han Yang, ${ }^{[a]}$ Yun Chi, ${ }^{[a]}$ Yu-Shan Yeh, ${ }^{[b]}$ Elisa Y. Li, ${ }^{[b]}$ Yi-Ming Cheng, ${ }^{[b]}$ Chia-Jung Hsu, ${ }^{[b]}$ Pi-Tai Chou, ${ }^{[b]}$ and Chin-Ti Chen ${ }^{[c]}$}

\begin{abstract}
Preparation of a new series of neutral metal complexes [(cod)Ir(fppz)] (1), [(cod) $\operatorname{Ir}(\mathrm{bppz})] \quad$ (2), [(cod) $\operatorname{Ir}($ fptz)] (3) and [(cod) $\operatorname{Ir}($ bptz)] (4), bearing one cod ligand and a pyridyl azolate chelate are reported. A single-crystal X-ray diffraction study of 3 reveals the expected distorted square-planar geometry. The lowest absorption band consists of $\operatorname{Ir}^{\mathrm{I}}$ atom increased triplet $\mathrm{d}_{\pi} \rightarrow \pi^{*}$ transitions ( ${ }^{3}$ MLCT), the assignment of which is firmly supported by the theoretical ap-
\end{abstract}

proaches. Complexes 1-4 exhibit weak phosphorescence in degassed solution at room temperature, whereas much more intense, solid-state phosphorescence appears in the range 622 $649 \mathrm{~nm}$. The pure MLCT emission was used as a prototypical model to address its remarkable spectral differences

Keywords: cyclooctene • iridium • phosphorescence $\cdot$ photochemistry pyridyl azolate from the $\mathrm{Ir}^{\mathrm{III}}$ isoquinoline pyrrolide complex (5), which has mainly ${ }^{3} \pi \pi$ phosphorescence. Complex $\mathbf{3}$ was used as a dopant to fabricate red-emitting phosphorescent organic light-emitting diodes (OLEDs). For the $7 \%$ doped device, a maximum brightness of $3010 \mathrm{~cd} \mathrm{~m}^{-2}$ was achieved at an applied voltage of $15 \mathrm{~V}$ and with CIE coordinates of $(0.56,0.33)$, demonstrating for the first time the potential of neutral $\mathrm{Ir}^{\mathrm{I}}$ complexes in OLED applications.

\section{Introduction}

Organometallic complexes possessing a third-row transitionmetal element are crucial for the fabrication of highly efficient organic light-emitting diodes (OLEDs). ${ }^{[1]}$ The strong spin-orbit coupling induced by a heavy-metal ion such as $\mathrm{Ir}^{\mathrm{III}}$, its isoelectronic $\mathrm{Os}^{\mathrm{II}}$, and even square-planar arranged $\mathrm{Pt}^{\mathrm{II}}$ metal ion, promotes an efficient intersystem crossing from the singlet to the triplet excited state manifold, which then facilitates strong electroluminescence through the har-

[a] C.-H. Fang, Y.-L. Chen, C.-H. Yang, Prof. Dr. Y. Chi Department of Chemistry, National Tsing Hua University Hsinchu 300 (Taiwan) Fax: $(+886) 357-20-864$ E-mail: ychi@mx.nthu.edu.tw

[b] Y.-S. Yeh, E. Y. Li, Dr. Y.-M. Cheng, C.-J. Hsu, Prof. Dr. P.-T. Chou Department of Chemistry, National Taiwan University Taipei 106 (Taiwan) Fax: (+886)223-695-208 E-mail: chop@ntu.edu.tw

[c] Prof. Dr. C.-T. Chen Institute of Chemistry, Academia Sinica Taipei 115 (Taiwan) nessing of both singlet and triplet excitons after the initial charge recombination. Because an internal luminescent quantum efficiency $\left(\eta_{\text {int }}\right)$ of about $100 \%$ could theoretically be achieved by the rapid $S_{1} \rightarrow T_{1}$ and $T_{1} \rightarrow S_{0}$ transitions, these heavy-metal-containing emitters would be superior to their fluorescent counterparts in future OLED design and fabrications. ${ }^{[2]}$ As a result, there is a continuous trend of shifting research endeavors from the traditional fluorescent emitters to these strongly phosphorescent third-row metal complexes involving $\mathrm{Ir}^{\mathrm{III}}$, Os ${ }^{\mathrm{II}}$, and $\mathrm{Pt}^{\mathrm{II}}$.

Moreover, the $\mathrm{Ir}^{\mathrm{III}}$ (or Os ${ }^{\mathrm{II}}$ ) complexes possess an octahedral molecular geometry and a $\mathrm{d}^{6}$ closed-shell configuration, for which the energy of the metal-centered $\mathrm{d} \rightarrow \mathrm{d}$ transitions is far greater than the metal-to-ligand charge transfer (MLCT) or the ligand-centered $\pi \pi^{*}$ transition. ${ }^{[3]}$ Thus, the thermal population to the dd excited state is minimized upon excitation to the MLCT or $\pi \pi^{*}$ states, ultimately increasing the radiative efficiency of phosphorescence and preserving the photostability. In another approach, preparation of luminescent $\mathrm{d}^{8} \mathrm{Pt}^{\mathrm{II}}$ complexes is more difficult because their distinctive square-planar geometry would allow a strong intermolecular $\pi-\pi$ stacking interaction, implying that they could be prone to poor illumination efficiencies or 
other unpredictable behavior due to the coexistence of $\pi-\pi$ stacking interactions or even the direct $\mathrm{M}-\mathrm{M}$ bonding in the condensed phases. ${ }^{[4]}$

Despite the above intrinsic limitation, many reports on the emissive properties of $\mathrm{Pt}^{\mathrm{II}}$ complexes were documented in the literature ${ }^{[5]}$ and utilization of these $\mathrm{Pt}^{\mathrm{II}}$ complexes as phosphorescent OLED dopants or emitters was also extensively investigated. ${ }^{[6]}$ Particularly, $\mathrm{Pt}^{\mathrm{II}}$-porphyrin complexes have become one of the most promising deep red light-emitting dyes, despite the large structural diversity found in the synthesized porphyrin frameworks. ${ }^{[7]}$ Furthermore, the use of cyclometalated ligands, or multidentate chelates, or Schiff base ligands has allowed the successful preparation of yellow-, green-, and even white-emitting OLEDs. ${ }^{[8]}$ More recently, small heterocyclic fragments such as pyrrole and azole have also been employed in assembling bright phosphorescent emitters with remarkable success. ${ }^{[9]}$

However, to our knowledge, extension of these OLED related investigations to the isoelectronic $\mathrm{Ir}^{\mathrm{I}}$ system has not been established so far. A few weak-emitting $\operatorname{Ir}^{\mathrm{I}}$ complexes were reported in the literature, ${ }^{[10]}$ and apparently this is most likely due to the lack of successful molecular design. We thus proposed that the chelating pyridyl azolate chromophore, which has been successfully used to prepare highly luminescent metal complexes, ranging from a main group element such as boron, ${ }^{[11]}$ to third-row heavy-transition-metal elements,${ }^{[12]}$ may serve as a good candidate for synthesizing and stabilizing the required $\operatorname{Ir}^{\mathrm{I}}$ metal complexes. Moreover, we speculate that due to the lower formal oxidation state of $1+$, this new system should exhibit an increased tendency to give the direct metal-to-ligand charge transfer (MLCT), compared with the common platinum and osmium system with the more positive $2+$ oxidation state. Thus, the access of these $\operatorname{Ir}^{\mathrm{I}}$ emissive complexes would provide an opportunity to understand the fundamental effect of metal oxidation state versus their observed photophysical behavior.

\section{Results and Discussion}

Preparation and characterization: The targeted $\operatorname{Ir}^{\mathrm{I}}$ derivative complex [(cod) $\operatorname{Ir}(f p p z)](\mathbf{1} ;(f p p z) H=3$-trifluoromethyl-5(2-pyridyl) pyrazole) was obtained by heating $[\{(\operatorname{cod}) \operatorname{Ir}(\mu-$ $\mathrm{Cl})\}_{2}$ ] with a slight excess of anionic pyridyl pyrazolate ligand (fppz) Na in THF solution. Moreover, three additional $\operatorname{Ir}^{\mathrm{I}}$ complexes, that is, [(cod) $\left.\operatorname{Ir}(\mathrm{bppz})\right](\mathbf{2}),[(\mathrm{cod}) \operatorname{Ir}(\mathrm{fptz})](\mathbf{3})$, and $[(\mathrm{cod}) \operatorname{Ir}(\mathrm{bptz})](\mathbf{4})$, were prepared by using the related chelating anions (bppz = 3-tert-butyl-5-(2-pyridyl)pyrazolate, fptz = 3-trifluoromethyl-5-(2-pyridyl) triazolate, and bptz = 3-tert-butyl-5-(2-pyridyl) triazolate). The structures of the pyridyl azoles and the $\operatorname{Ir}^{\mathrm{I}}$ complexes are depicted in Scheme 1. It is notable that both the single crystals and pulverized powders of these $\operatorname{Ir}^{\mathrm{I}}$ complexes are stable in air at room temperature over one day. However, upon dissolution in organic solvents, both chlorinated and non-chlorinated, they became more reactive and formed brown intractable products within a period of $2-3 \mathrm{~h}$. As a result, all routine (fppz) $\mathrm{H}_{\mathrm{r}} \mathrm{R}=\mathrm{CF}_{3}$ (bppz)H, R = $\mathrm{tBu}$<smiles>[R]c1cc2n(n1)[I-]1(C3=CCCC3)CCC23C=CC=CN31</smiles>

(1) $\mathrm{R}=\mathrm{CF}_{3}$

(2) $\mathrm{R}=t \mathrm{Bu}$

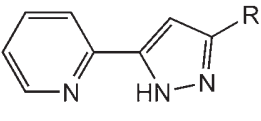

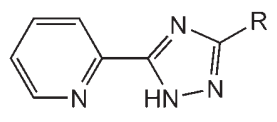

(fptz) H, R $=\mathrm{CF}_{3}$ (bptz) $\mathrm{H}, \mathrm{R}=t \mathrm{Bu}$

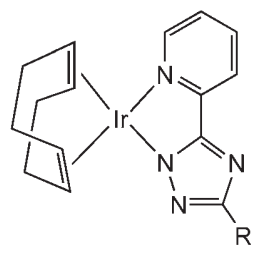

(3) $\mathrm{R}=\mathrm{CF}_{3}$

(4) $\mathrm{R}=t \mathrm{Bu}$
Scheme 1.

manipulations such as recrystallization or preparing samples for NMR analyses were performed under anaerobic conditions. The cod ligand is essential in stabilizing these metal complexes. All attempts at replacing the cod ligand with other monodentate or even bidentate chelates such as $\mathrm{CO}$, 2,2'-bipyridine, or 1,2-bis(diphenylphosphino)ethane failed to give any stable and isolable product.

For further confirmation of the structure of these $\operatorname{Ir}^{\mathrm{I}}$ complexes, an fptz-substituted derivative $\mathbf{3}$ was selected for a single-crystal X-ray diffraction study. As indicated in Figure 1, the molecule shows square-planar stereochemistry at the iridium atom, which is defined by the $\mathrm{C}=\mathrm{C}$ centroids of the 1,5-cod ligand and the $\mathrm{N}(1)$ and $\mathrm{N}(4)$ atoms of the fptz ligand. Furthermore, the anionic $\operatorname{Ir}(1)-\mathrm{N}(1)$ distance $(2.028(8) \AA)$ is shorter than the corresponding $\operatorname{Ir}(1)-\mathrm{N}(4)$ distance $(2.114(9) \AA)$ of the neutral pyridine ligand, but this alternation of bond length has no obvious influence on the trans-Ir-C(olefin) bonds, because all of the $\mathrm{Ir}-\mathrm{C}$ bond

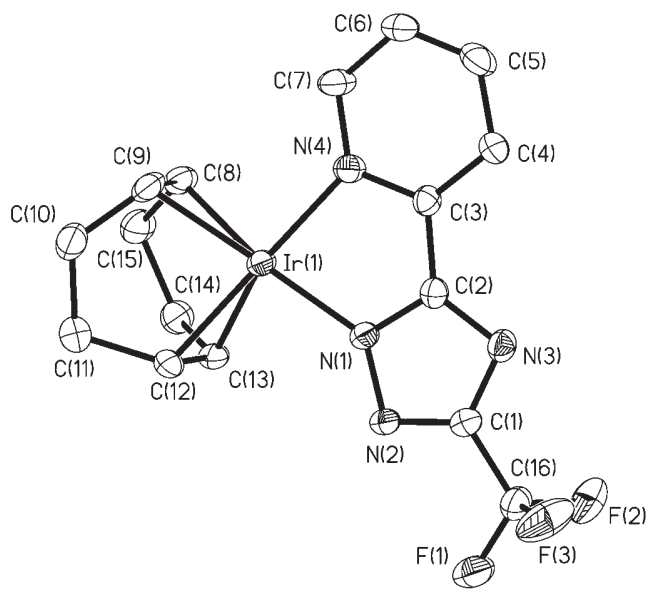

Figure 1. Molecular structure of complex 3 (ORTEP diagram with thermal ellipsoids shown at the $30 \%$ probability level). Selected bond lengths $[\AA]$ and angle $\left[{ }^{\circ}\right]: \operatorname{Ir}(1)-\mathrm{N}(1) 2.028(8), \operatorname{Ir}(1)-\mathrm{N}(4) 2.114(9), \operatorname{Ir}(1)-\mathrm{C}(13)$ $2.100(10), \quad \operatorname{Ir}(1)-\mathrm{C}(9) \quad 2.111(11), \quad \operatorname{Ir}(1)-\mathrm{C}(12) \quad 2.121(10), \quad \operatorname{Ir}(1)-\mathrm{C}(8)$ 2.130(11); N(1)-Ir(1)-N(4) 77.8(3). 
lengths to cod ligand fall in a very narrow range of $2.100(10)$ to $2.130(10) \AA$. For a further comparison, both the Ir-N distances of the fppz chelate in $\mathbf{3}$ (2.028 and $2.114 \AA$ ) are shorter than those observed in the octahedral $\mathrm{Ir}^{\mathrm{III}}$ complexes $\left[\left(\mathrm{C}^{\wedge} \mathrm{N}\right)_{2} \operatorname{Ir}(\mathrm{fppz})\right], \mathrm{C}^{\wedge} \mathrm{N}=$ cyclometalated ligand, $(2.096-2.149 \AA) .{ }^{[13]}$ Such a result is contradictory to the anticipation of a longer bond length for the $\operatorname{Ir}^{\mathrm{I}}$ complexes, showing the reduced trans labilization effect of the cod ligand versus that of the much stronger, trans iridiumphenyl $\sigma$ bonding observed in the $\operatorname{Ir}^{\mathrm{III}}$ complexes.

Photophysical properties: The absorption spectra of complexes 1-4 in $\mathrm{CH}_{2} \mathrm{Cl}_{2}$ are shown in Figure 2. The strong absorption bands in the UV region are assigned to the spin-al-

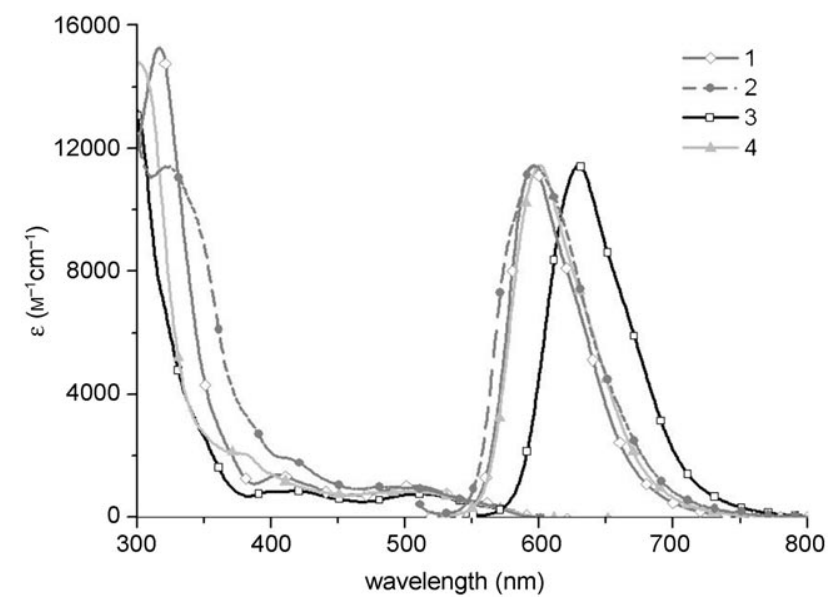

Figure 2. UV/Vis absorption spectra of complexes 1-4 recorded in solution in $\mathrm{CH}_{2} \mathrm{Cl}_{2}$, and the respective solid-state emission spectra obtained from a thin-film sample at room temperature.

lowed ${ }^{1} \pi \pi^{*}$ transition of the pyridyl azolate ligands. ${ }^{[14]}$ The lower-lying energy absorption at about $420 \mathrm{~nm}$ is broad with some structural features. It seems reasonable to assign this broad absorption feature to the multiple components of the $\mathrm{d}_{\pi} \rightarrow \pi^{*}$ (or MLCT) transition on the basis of their positions and relative intensities. ${ }^{[15]}$ It is notable that all complexes have another weak, but distinct absorption band that extends into the lower-energy region of 550-560 nm. Such a peak could be attributed to the strong coupling of spin-allowed ${ }^{1} \mathrm{MLCT}$ and the spin-forbidden ${ }^{3} \mathrm{MLCT}$ (or even ${ }^{3} \pi \pi$ ) absorption bands. Finally, all complexes show very similar absorption patterns, implying that the alkyl substituents of the chelate ligands and even their intrinsic properties (i.e., pyrazolate or triazolate) impose only a minor influence on their photophysical properties. Further support of these assignments will be elaborated in the section on theoretical approaches (see below).
Figure 2 depicts the emission spectra of 1-4 measured by using vacuum-deposited thin-film samples, whereas the photophysical data in both solution and as thin films are listed in Table 1. As for the emission properties in solution, compounds 1, 2, and 4 exhibit peaks at $613-625 \mathrm{~nm}$, whereas the peak wavelength of $\mathbf{3}$ is relatively longer, at $630 \mathrm{~nm}$. The results may be tentatively rationalized by the electron-withdrawing properties of the triazolate moiety, resulting in an electron deficiency of the adjacent pyridyl moiety (LUMO) and hence decreasing the HOMO-LUMO gap. A detailed elaboration of this effect will be given in the section on theoretical approaches. All of these four complexes are weakly emissive in solution, with a quantum efficiency, $\Phi_{\mathrm{p}}$, measured to be $\leq 10^{-3}$ in degassed $\mathrm{CH}_{2} \mathrm{Cl}_{2}$, and the observed phosphorescence lifetime, $\tau_{\text {obs }}$ was $<10$ ns (see Table 1$)$. The radiative lifetime calculated by $\tau_{\mathrm{f}} \approx \tau_{\text {obs }} / \Phi_{\mathrm{p}}$ was deduced to be $\leq 5 \mu$ s for 1-4. This value is comparable to that of the red-emitting Ir III complexes. ${ }^{[16]}$ Regarding the low emission quantum efficiency in solution, we believe that the formally $\mathrm{d}^{8}$ square-planar excited state may be subject to nonradiative deactivation through strong interaction with solvent, and/or nontotal symmetric distortion, giving the observed poor luminescence efficiency in the fluid state. These effects are to be suppressed in the solid state or solid matrices, and a relatively unperturbed emission may thus be expected. Support of this viewpoint is given by the more intense quantum efficiency $\left(\Phi_{\mathrm{p}}>5 \%\right)$ for 1-4 in solid film (see Table 1$)$. Nevertheless, it is worthy to note that the emission of the solid sample of $\mathbf{1}, \mathbf{2}$, and $\mathbf{4}$, as listed in Table 1, exhibited a slight blue-shift in comparison to that in solution. It appears that the difference in emission energy between solution and solid state is likely to be caused by the solvent relaxation in solution, the result of which usually leads to the lowering of the emission energy.

Electroluminescence: In view of possible technical applications, it is worthy to mention that complex $\mathbf{3}$, due to its saturated red photoluminescence (PL) emission $(630 \mathrm{~nm})$ as well as the highest emission yield among compounds 1-4, has been utilized for the preparation of preliminary OLEDs with a configuration of ITO/NPB $(30 \mathrm{~nm}) / \mathrm{CBP}: 3(30 \mathrm{~nm}) /$ $\mathrm{BCP}(10 \mathrm{~nm}) / \mathrm{AlQ}_{3}(30 \mathrm{~nm}) / \mathrm{LiF}(1 \mathrm{~nm}) / \mathrm{Al}(150 \mathrm{~nm})$, where

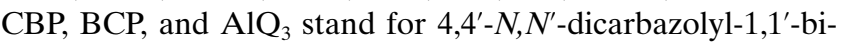
phenyl, 2,9-dimethyl-4,7-diphenyl-1,10-phenanthroline, and tris(8-hydroxyquinolinato) aluminum(III), respectively. This multilayer configuration was adopted from those first re-
Table 1. Photophysical properties of $\operatorname{Ir}^{\mathrm{I}}$ complexes 1-5.

\begin{tabular}{llllll}
\hline & abs $\lambda_{\max }\left[\varepsilon \times 10^{-3}, \mathrm{M}^{-1} \mathrm{~cm}^{-1}\right]$ & $\mathrm{PL}^{[\mathrm{a}]} \lambda_{\max }[\mathrm{nm}]$ & $\Phi[\%]^{[\mathrm{a}]}$ & $\tau_{\mathrm{obs}}[\mathrm{ns}]^{[\mathrm{a}]}$ & $\tau_{\mathrm{r}}[\mu \mathrm{s}]$ \\
\hline $\mathbf{1}$ & $316(15.3), 404(1.4), 506(1.1)$ & $614[596]$ & $0.046[8]$ & $1.38[305]$ & 3.0 \\
$\mathbf{2}$ & $320(11.4), 383(3.2), 411(2.0), 485(1.0)$ & $613[596]$ & $0.028[5]$ & $1.40[250]$ & 5.0 \\
$\mathbf{3}$ & $349(2.7), 420(0.9), 510(0.8)$ & $630[630]$ & $0.10[12]$ & $2.06[360]$ & 2.0 \\
$\mathbf{4}$ & $301(14.8), 375(2.1), 511(0.9)$ & $625[599]$ & $0.033[7]$ & $1.47[280]$ & 4.5 \\
$\mathbf{5}$ & $268(47.4), 369(11.8), 438(17.0), 460(15.5)$ & 625 & 37 & $2.2 \times 10^{4}$ & 59 \\
\hline
\end{tabular}

[a] The absorption and emission spectra were recorded in degassed $\mathrm{CH}_{2} \mathrm{Cl}_{2}$ at room temperature, and the solid-state spectra were measured by using vacuum-deposited thin-film samples and are listed in square brackets. 
ported by Thompson and Forrest, ${ }^{[17]}$ whereas the respective efficiency data employing 7 and $14 \%$ of $\mathbf{3}$ are summarized in Table 2. All devices exhibit a strong electroluminescent

ficiency of $0.55 \mathrm{~lm} \mathrm{~W} \mathrm{~m}^{-1}$ at a current density of $20 \mathrm{mAcm}^{-2}$, and a maximum brightness of $3010 \mathrm{~cd} \mathrm{~m}^{-2}$ recorded at $15 \mathrm{~V}$, confirming the potential of $\mathbf{3}$ to serve as a dopant. Upon increasing the dopant concentration to $14 \%$, the maximum brightness slightly decreased to $2171 \mathrm{~cd} \mathrm{~m}^{-2}$, whereas other efficiency data also decreased to $0.86 \%, \quad 1.28 \mathrm{~cd} \mathrm{~A}^{-1}, \quad$ and $0.42 \mathrm{~lm} \mathrm{~W}^{-1}$, respectively. In comparison, these device efficiencies as well as their color purity seem inferior to those of the Ir $^{\mathrm{III}}$-based red-emitting

signal (EL) centered at 614-616 nm (Figure 3), which is slightly blue-shifted from the photoluminescence observed in both solution and solid state, together with two weak and broad emission signals covering the shorter wavelength region of $420-500 \mathrm{~nm}$. These emission signals, to a certain extent, perturbed the main red emission and then shifted the CIE chromaticity to a value of $(0.56,0.33)$ and $(0.53$, 0.34 ) for the 7 and $14 \%$ doped device, respectively. The short wavelength EL can be attributed to the CBP host fluorescence, ${ }^{[18]}$ whereas the identity of the second longer wavelength emission at about $500 \mathrm{~nm}$ is not known at this stage.

The first device gave an external quantum efficiency of $1.16 \%$, a luminance efficiency of $1.84 \mathrm{~cd} \mathrm{~A}^{-1}$ and a power ef- complexes ${ }^{[19]}$ for which the higher oxidation stability of the $\mathrm{Ir}^{\mathrm{III}}$ core and the fully saturated coordination environment around the metal center are believed to be the key factors in causing such dramatic changes in device performances.

Theoretical approaches: Theoretical confirmation of the underlying basis for the photophysical properties of compounds 1-4 was provided by ab initio MO calculations. By using the TD-B3LYP method incorporating the B3LYP/6$31 \mathrm{G}\left(\mathrm{d}^{\prime}, \mathrm{p}^{\prime}\right)$ optimized geometry, the vertical (i.e., FranckCondon) excitation energy from the ground-state to lowlying excited states was calculated. Figure 4 depicts the features of the two lowest unoccupied (LUMO and LUMO+ a)
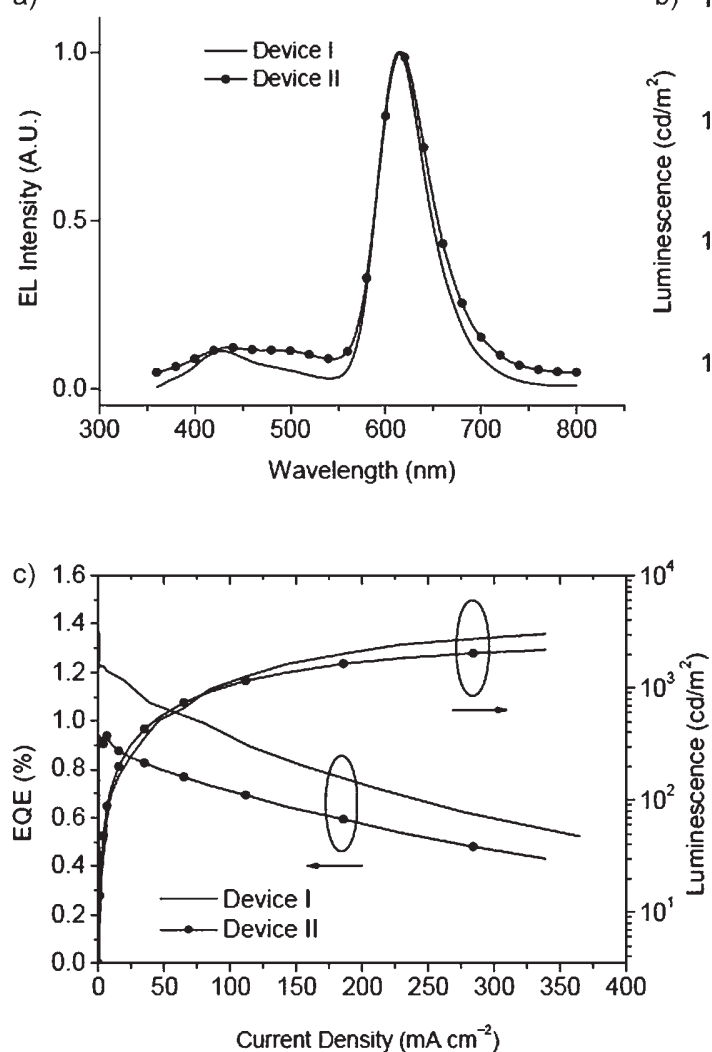

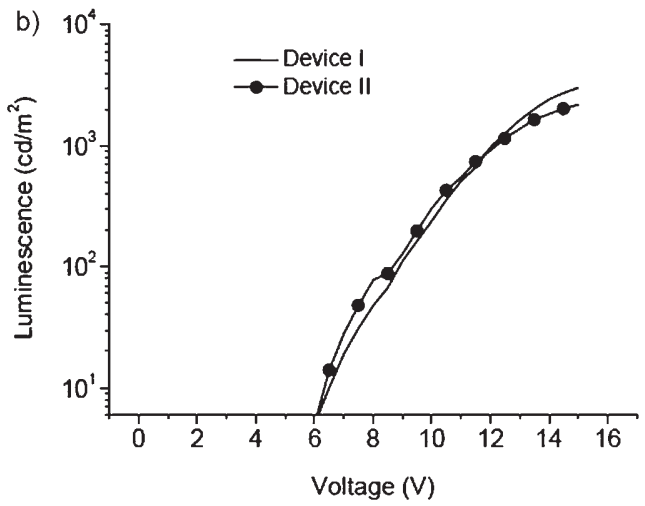

d)

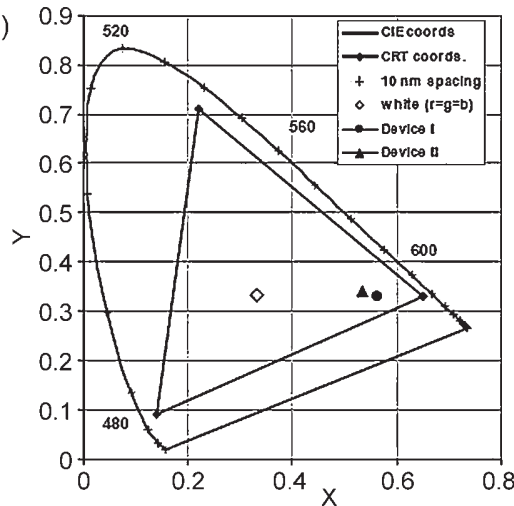

Figure 3. a) EL spectra of the doped OLED devices I (7\%) and II (14\%); b) voltage dependence of the EL intensity of devices I and II; c) dependence of external quantum efficiencies and luminescence versus current density; d) $1931 \mathrm{CIE}$ color chromaticity diagram. EQE = external quantum efficiency. 


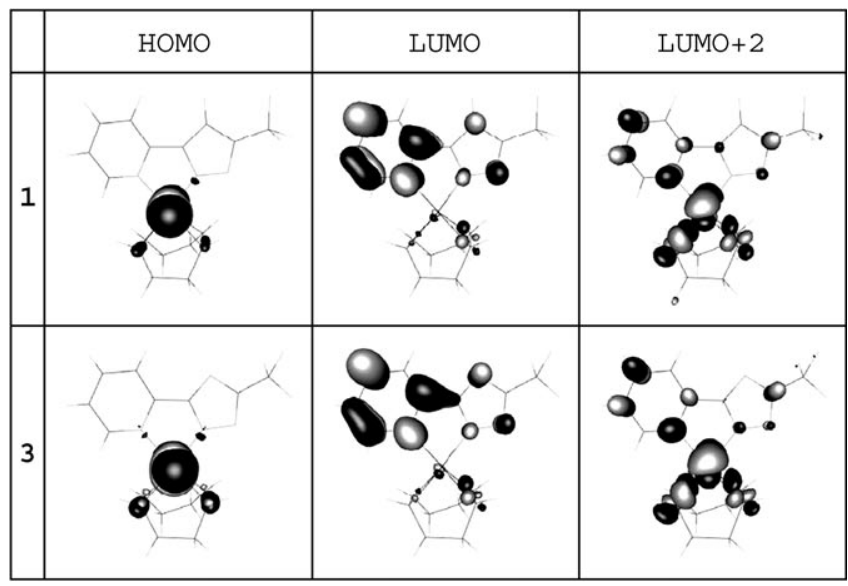

Figure 4. Selected frontier orbitals for the $\mathrm{CF}_{3}$-substituted complexes $\mathbf{1}$ and 3 .

2) and the highest occupied (HOMO) frontier orbitals for complexes $\mathbf{1}$ and $\mathbf{3}$, which are mainly involved in the lowerlying transitions, whereas the descriptions and the energy gap of all complexes are listed in Table 3. Apparently, the

Table 3. The calculated electronic transitions of complexes 1-4.

\begin{tabular}{llllll}
\hline Complex & & $\lambda[\mathrm{nm}]$ & $E[\mathrm{eV}]$ & $f$ & Assignment \\
\hline $\mathbf{1}$ & $\mathrm{S}_{1}$ & 530.2 & 2.34 & 0.0029 & HOMO $\rightarrow$ LUMO $(+96 \%)$ \\
& $\mathrm{T}_{1}$ & 585.3 & 2.12 & & HOMO $\rightarrow$ LUMO $(+98 \%) ;$ \\
& & & & & HOMO $\rightarrow$ LUMO $+2(+8 \%)$ \\
$\mathbf{2}$ & $\mathrm{S}_{1}$ & 522.9 & 2.37 & 0.0026 & HOMO $\rightarrow$ LUMO $(+96 \%)$ \\
& $\mathrm{T}_{1}$ & 577.4 & 2.15 & & HOMO $\rightarrow$ LUMO $(+98 \%) ;$ \\
& & & & & HOMO $\rightarrow$ LUMO $+2(+8 \%)$ \\
$\mathbf{3}$ & $\mathrm{S}_{1}$ & 550.1 & 2.25 & 0.0026 & HOMO $\rightarrow$ LUMO $(+95 \%)$ \\
& $\mathrm{T}_{1}$ & 612.3 & 2.02 & & HOMO $\rightarrow$ LUMO $(+99 \%) ;$ \\
& & & & & HOMO $\rightarrow$ LUMO $+2(+7 \%)$ \\
$\mathbf{4}$ & $\mathrm{S}_{1}$ & 523.3 & 2.37 & 0.0027 & HOMO $\rightarrow$ LUMO $(+96 \%)$ \\
& $\mathrm{T}_{1}$ & 579.1 & 2.14 & & HOMO $\rightarrow$ LUMO $(+98 \%) ;$ \\
& & & & HOMO $\rightarrow$ LUMO $+2(+8 \%)$
\end{tabular}

electron densities of the singlet and triplet states for the HOMO are largely located on the central metal atom, for example, $>90 \%$ for the iridium $\mathrm{d}_{\pi}$ orbital, whereas those of the LUMO are mainly distributed on the pyridyl moiety (e.g., $>65 \%$ in LUMO). This result indicates that the lowest electronic transition is predominantly MLCT in character. Note that the lowest-lying triplet state is contributed, in a small part, by the LUMO +2 orbital, which possesses the azolate (pyrazolate or triazolate) moiety. One can thus expect that the azolate moiety of complexes 1-4 may act as a substituent to the pyridyl chromophore and hence affect the LUMO energy level, resulting in an alternation of the photophysical properties. For example, in comparison to the pyrazolate group in $\mathbf{1}$ and $\mathbf{2}$, the stronger electron-withdrawing triazolate moiety in $\mathbf{3}$ should lead to a greater electron deficiency of the pyridine moiety, to which the LUMO is mainly contributed, leading to a decrease of the energy gap for $\mathbf{3}$ in comparison to that for complexes $\mathbf{1}$ and $\mathbf{2}$. Conversely, the addition of an electron-donating tert-butyl substituent to the triazolate moiety, as in the case of $\mathbf{4}$, plays a complementary role to compensate the electron-withdrawing triazolate moiety. It is thus not surprising that complex 4 reveals a phosphorescent peak wavelength similar to that of complexes $\mathbf{1}$ and $\mathbf{2}$. As for more quantitative detail, Table 4 lists

Table 4. Contribution of each constituent to the frontier orbitals for complexes $\mathbf{1}$ and $\mathbf{3}$.

\begin{tabular}{llcrlc}
\hline MO & $E[\mathrm{eV}]$ & \multicolumn{5}{c}{ Contributing percentage } \\
complex 1 & & iridium & cod & pyridine & pyrazolate \\
\hline LUMO+2 & -0.32 & 40.3 & 30.7 & 23 & 6 \\
LUMO +1 & -1.32 & 1.3 & 1.7 & 85.1 & 11.9 \\
LUMO & -2.1 & 7.6 & 11.7 & 69 & 10.4 \\
HOMO & -5.33 & 86.3 & 9.4 & 1.8 & 2.4 \\
HOMO-1 & -6.08 & 33.2 & 17.1 & 5.6 & 44 \\
\hline complex 3 & & iridium & cod & pyridine & triazolate \\
\hline LUMO+2 & -0.54 & 40.6 & 30.9 & 21.1 & 7.4 \\
LUMO+1 & -1.55 & 0.6 & 1.2 & 87.6 & 10.6 \\
LUMO & -2.39 & 7.8 & 11.8 & 66.6 & 13.8 \\
HOMO & -5.55 & 86.3 & 9.8 & 1.7 & 2.3 \\
HOMO-1 & -6.37 & 37.8 & 16.0 & 8.6 & 37.6 \\
\hline
\end{tabular}

the MO compositions intuitively by calculating the densityof-states spectra of complexes $\mathbf{1}$ and $\mathbf{3}$, respectively, in terms of the contribution from each of the constituents. The result provides a more quantitative overview in that about $14 \%$ of the LUMO is contributed by the triazolate group in $\mathbf{3}$, whereas only about $10 \%$ is from the pyrazolate moiety in $\mathbf{1}$. As a result, the lowest $\mathrm{T}_{1} \rightarrow \mathrm{S}_{0}$ transitions calculated for $\mathbf{1}$ and $\mathbf{3}$ (585 and $612 \mathrm{~nm}$, respectively) are in very good agreement with the tendency obtained from the phosphorescence (1: 614 and 3: $630 \mathrm{~nm}$ in $\mathrm{CH}_{2} \mathrm{Cl}_{2}$ solution, see Table 1). Note that the deviation of the current theoretical approach from the experimental results may plausibly be explained by the negligible solvation effects in the gas-phase ab initio approach. Therefore, the theoretical level adopted here is suitable for studying the photophysical properties of $\mathrm{Ir}^{\mathrm{I}}$ complexes 1-4 in a qualitative manner.

${ }^{3}$ MLCT versus ${ }^{3} \pi \pi$ properties: From the photophysical point of view, $\operatorname{Ir}^{\mathrm{I}}$ complexes presented here provide an excellent model to examine the fundamental difference for metal complexes possessing ether pure $\pi \pi^{*}$ and/or MLCT as the lowest-lying state. For example, one might expect that a MLCT dominant transition involving metal (e.g., $\left.\operatorname{Ir}^{\mathrm{I}}\right) \mathrm{d}_{\pi}$ electrons should greatly enhance the spin-orbit coupling. This can be theoretically rationalized by: i) the d orbital of the heavy metal $\left(\operatorname{Ir}^{\mathrm{I}}\right)$ directly is directly involved in the transition, and; ii) the $d_{\pi}-\pi^{*}$ transition requires an orbital flipping, the tensor of which can be utilized to facilitate the spin-orbit coupling. As a result, one would expect the singlet-triplet mixing element $\left\langle T_{1}\left|H_{\mathrm{so}}\right| S_{0}\right\rangle$ (or $\left\langle S_{1}\left|H_{\mathrm{so}}\right| T_{1}\right\rangle$ ) to be large, giving rise to a significant extent of mixing between singlet and triplet states, such that the phosphorescence radiative lifetime is expected to be short, consistent with the rather short radiative lifetime of $\leq 5 \mu$ s for $\mathbf{1}-\mathbf{4}$ in $\mathrm{CH}_{2} \mathrm{Cl}_{2}$. 
Another key feature is related to the $S_{1}-T_{1}$ energy gap. ${ }^{[20]}$ The energy difference between singlet $\left(\mathrm{S}_{1}\right)$ and triplet $\left(\mathrm{T}_{1}\right)$ states, $\Delta E_{\mathrm{S} 1-\mathrm{T} 1}$, mainly lies in the matrix element $J$ associated with the electron repulsion due to the electron exchange, so that:

$$
\Delta E_{\mathrm{S} 1-\mathrm{T} 1}=E\left(\mathrm{~S}_{1}\right)-E\left(\mathrm{~T}_{1}\right) \approx 2 J
$$

where the $J$ value is essentially equivalent to the overlap integral between the electron wave functions in the $S_{1}$ and $T_{1}$ states. For the system with pure MLCT configurations in both lowest singlet and triplet states, $J$ can be expressed as Equation (1)]:

$J=\left\langle\mathrm{d}_{\pi}(1) \pi^{*}(2)\left|\frac{e}{r_{12}}\right| \pi(2) \pi^{*}(1)\right\rangle$

where the numbers refer to the electrons occupying these orbitals and $e / r_{12}$ represents the repulsion between exchanging of the electrons. As a simplified approach, the latter can be factored out so that $J$ is qualitatively perceived to be proportional to the overlap of participating orbitals, which can be expressed as Equation (2):

$J_{\mathrm{d}_{\pi}, \pi^{*}} \propto\left\langle d_{\pi}(1) \pi^{*}(2) \mid d_{\pi}(2) \pi^{*}(1)\right\rangle$

Conversely, for the case of iridium complexes possessing mainly $\pi \pi^{*}$ characters in both $\mathrm{S}_{1}$ and $\mathrm{T}_{1}, J$ can be expressed as Equation (3):

$J_{\pi, \pi^{*}} \propto\left\langle\pi(1) \pi^{*}(2) \mid \pi(2) \pi^{*}(1)\right\rangle$

It is thus clear that $J_{\pi, \pi^{*}}$ is, in general, much larger than $J_{\mathrm{d}_{\pi}, \pi^{*}}$ because the integral expressed in Equation (3) is greater than that in Equation (2) due to the better orbital overlap between $\pi \pi^{*}$ than that of $\mathrm{d}_{\pi} \pi^{*}$. As a result, $\Delta E_{\mathrm{S}_{1}-\mathrm{T}_{1}}$ for complexes possessing $\pi \pi^{*}$ as the lowest-lying transition in both singlet and triplet manifolds is expected to be significantly larger than that of complexes 1-4.

Experimentally, due to the low oxidation state for the $\operatorname{Ir}^{\mathrm{I}}$ cation, a search of $\operatorname{Ir}^{\mathrm{I}}$ complexes possessing mainly $\pi \pi^{*}$ as the lowest-lying state and having an energy gap similar to those of $\mathbf{1 - 4}$ is difficult. Alternatively, $\mathrm{Ir}^{\mathrm{III}}$ complexes should serve as better candidates due to their high oxidation states and thus more-stabilized metal d orbitals. We thus designed and synthesized isoquinoline pyrrolide complex $\mathbf{5}$ and expected that complex $\mathbf{5}$ may serve as the $\pi \pi^{*}$ extreme due to

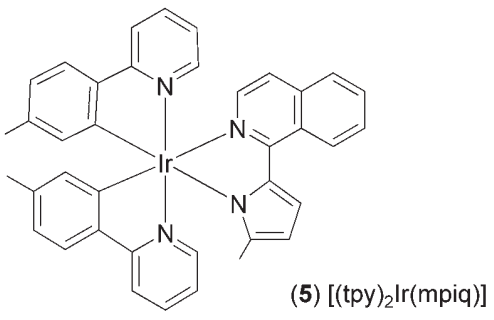

the rise of energy of the $\pi$ orbital in the isoquinoline moiety. As depicted in Figure 5, complex 5 exhibits unique phosphorescence with a peak wavelength $\left(\lambda_{\max }\right)$ at $625 \mathrm{~nm}$. In

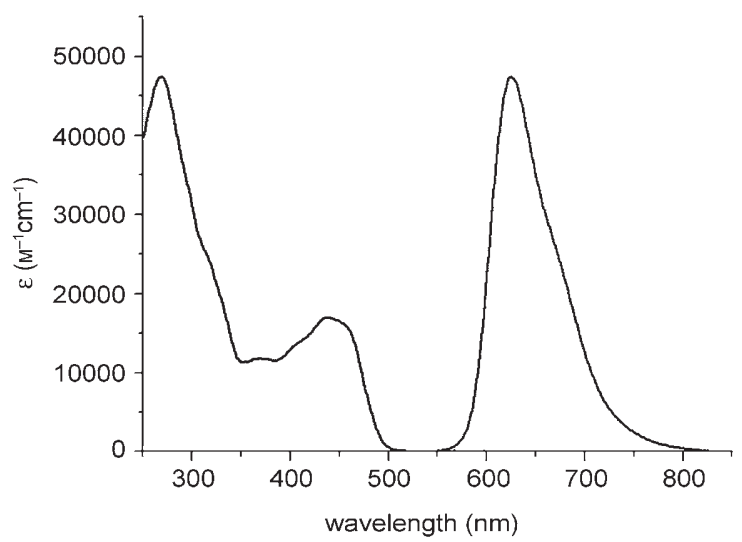

Figure 5. UV/Vis absorption and emission spectra of complex $\mathbf{5}$ in $\mathrm{CH}_{2} \mathrm{Cl}_{2}(298 \mathrm{~K})$.

contrast to the strongly mixed $\mathrm{S}_{1}$ (absorption) and $\mathrm{T}_{1}$ (phosphorescence) spectra in 1-4 (see Figure 2), it clearly exhibits a significantly large energy gap of about $11 \mathrm{kcal} \mathrm{mol}^{-1}$ between $\mathrm{S}_{1}(\approx 500 \mathrm{~nm})$ and $\mathrm{T}_{1}(\approx 620 \mathrm{~nm})$ states. Figure $6 \mathrm{de}$ picts the features of the highest-occupied (HOMO) and two lowest-unoccupied (LUMO and LUMO+1) frontier orbitals mainly involved in the electronic transition, and the descriptions and the energy gaps of each transition are listed in Table 5. Apparently, the electron densities of the HOMO are located mainly on the pyrrolide fragment of the mpiq

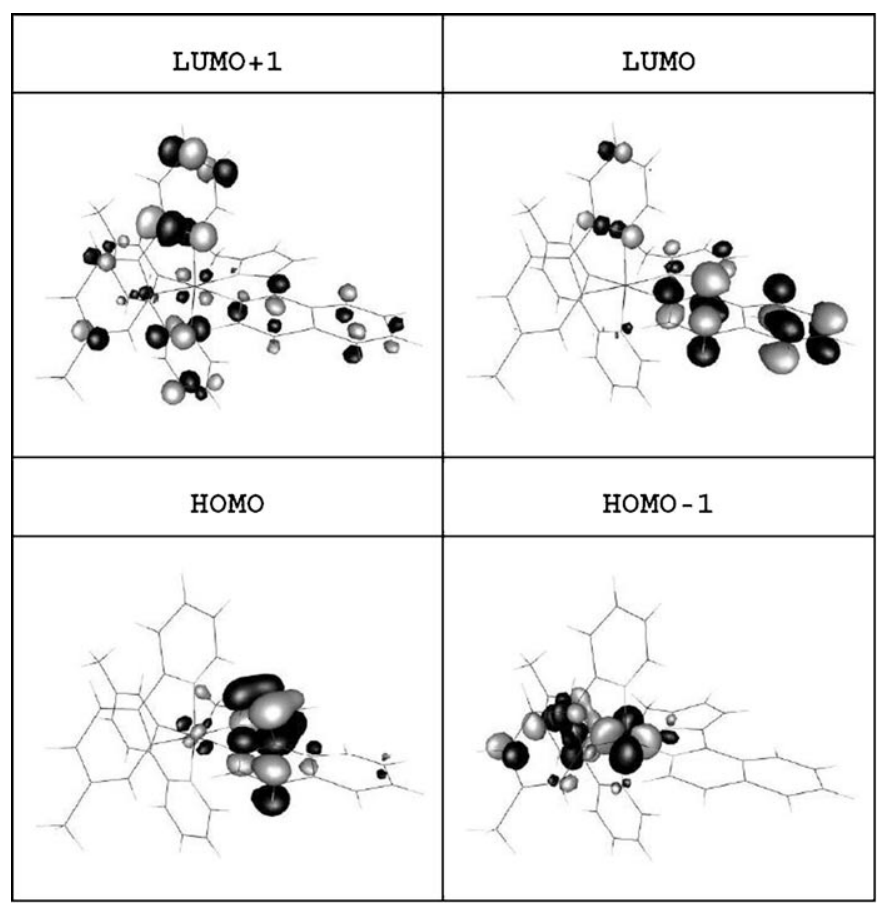

Figure 6. Selected frontier orbitals of complex 5. 
Table 5. The calculated energy levels of the low-lying excited-state transitions for $\mathbf{5}$.

\begin{tabular}{|c|c|c|c|c|}
\hline States & $\lambda[\mathrm{nm}]$ & $E[\mathrm{eV}]$ & $f$ & Assignment \\
\hline $\mathrm{S}_{1}$ & 450 & 2.76 & 0.0320 & $\begin{array}{l}\mathrm{HOMO} \rightarrow \text { LUMO }(+54 \%) \\
\mathrm{HOMO} \rightarrow \mathrm{LUMO}+1(+41 \%)\end{array}$ \\
\hline $\mathrm{S}_{2}$ & 429 & 2.89 & 0.0145 & $\begin{array}{l}\text { HOMO }-1 \rightarrow \text { LUMO }(+60 \%) ; \\
\text { HOMO }-1 \rightarrow \text { LUMO }+1(+25 \%) \\
\text { HOMO } \rightarrow \text { LUMO }+2(8 \%)\end{array}$ \\
\hline $\mathrm{T}_{1}$ & 603 & 2.06 & 0.0000 & $\begin{array}{l}\text { HOMO } \rightarrow \text { LUMO }(+95 \%) \\
\text { HOMO } \rightarrow \text { LUMO }+1(17 \%)\end{array}$ \\
\hline $\mathrm{T}_{2}$ & 464 & 2.67 & 0.0000 & $\begin{array}{l}\text { HOMO }-1 \rightarrow \text { LUMO }+1(+39 \%) \\
\text { HOMO }-1 \rightarrow \text { LUMO }(+36 \%) ; \\
\text { HOMO }-3 \rightarrow \text { LUMO }+2(+9 \%)\end{array}$ \\
\hline
\end{tabular}

ligand $(>95 \%)$, whereas only a very minor contribution is located on the $\operatorname{Ir}^{\mathrm{III}}$ atom $(<5 \%$, see Table 6$)$. Conversely, those of the LUMO are distributed over the entire isoquino-

Table 6. Contribution of each constituent to the frontier orbitals for complex 5.

\begin{tabular}{lllllll}
\hline MO & $\begin{array}{l}E \\
{[\mathrm{eV}]}\end{array}$ & Iridium & Pyrrolide & Isoquinoline & Pyridine & $\begin{array}{l}p \text { - } \\
\text { Tolyl }\end{array}$ \\
\hline LUMO +1 & -1.08 & 4.0 & 3.6 & 19.8 & 54.0 & 18.6 \\
LUMO & -1.24 & 1.3 & 12.4 & 62.3 & 17.8 & 6.2 \\
HOMO & -4.49 & 3.8 & 68.7 & 25.6 & 0.8 & 1.0 \\
HOMO-1 & -4.82 & 42.1 & 5.6 & 1.1 & 7.0 & 44.3 \\
\hline
\end{tabular}

line moiety. The results clearly indicate that the lowest energy transition in both $\mathrm{S}_{0} \rightarrow \mathrm{S}_{1}$ and $\mathrm{S}_{0} \rightarrow \mathrm{T}_{1}$ manifolds are dominated by $\pi \pi^{*}$ character. The lowest triplet state calculated for $5(602 \mathrm{~nm})$ is in good agreement with that obtained experimentally $(625 \mathrm{~nm})$. According to Table $5, \Delta E_{\mathrm{S} 1-\mathrm{T} 1}$ was calculated to be as large as $16 \mathrm{kcal} \mathrm{mol}^{-1}$ for complex $\mathbf{5}$. The value is comparable to the experimentally resolved value of $11 \mathrm{kcal} \mathrm{mol}^{-1}$ and reveals a typical $\Delta E_{\mathrm{S} 1-\mathrm{T} 1}$ for the $\pi \pi^{*}$ transition character. On the other hand, $\Delta E_{\mathrm{S} 1-\mathrm{T} 1}$ were calculated to be $\leq 5.2 \mathrm{kcal} \mathrm{mol}^{-1}$ for $\mathbf{1 - 4}$ (see Table 3), supporting the great $\mathrm{S}_{1}-\mathrm{T}_{1}$ mixing observed experimentally.

\section{Conclusion}

We have synthesized a new series of $\operatorname{Ir}^{\mathrm{I}}$ azolate complexes 1-4 with an aim to probe their fundamental properties and application in OLEDs. They possess pure MLCT character for both $S_{0}-S_{1}$ and $S_{0}-T_{1}$ transitions with rather lower $S_{0}-T_{1}$ energy gaps of $\leq 16700 \mathrm{~cm}^{-1}(\geq 590 \mathrm{~nm})$, which are rare in comparison with the Ir ${ }^{\mathrm{III}}$ complexes showing a similar emission energy gap. As for probing the fundamental properties, complexes 1-4 serve as an excellent model for the case of a pure MLCT transition, in which the proximity between $S_{1}$ and $\mathrm{T}_{1}$ states is firmly supported by the strong spectral overlap. Conversely, complex 5, possessing dominant $\pi \pi^{*}$ character in both $S_{1}$ and $T_{1}$, greatly increases the $S_{1}-T_{1}$ separation, as supported experimentally and theoretically. A semiclassical theory incorporating the electron repulsion during exchange has thus been developed to rationalize the results. Accordingly, $\Delta E_{\mathrm{S} 1-\mathrm{T} 1}$ may be used as a feature to qualitatively examine the excited-state properties, that is, the MLCT versus $\pi \pi^{*}$ transition, particularly for the secondand third-row transition-metal complexes. From the application viewpoint, despite their weak luminescent efficiency in the solution phase, possibly due to the strong solvent interaction and/or nontotal symmetric distortion, much more intense emission was observed in the solid film. As a result, a decent EL performance with a quantum efficiency of about $1.2 \%$ could be achieved for complex 3 . Thus, we present a new and conceptual design of $\operatorname{Ir}^{\mathrm{I}}$ pyridyl azolate complexes suited to the red emitters for OLEDs. The relatively poor performances for OLEDs employing these complexes are likely to be due to the inferior chemical stability, which is also the result of poor resistance to oxidation. However, we also wish to emphasize that, in this paper, our main goal was to deliver a new concept for OLED fabrication by using previously unknown $\operatorname{Ir}^{\mathrm{I}}$ phosphors, and not to achieve the best phosphorescent materials. Of course, further realization of this concept awaits new methodology for improving the chemical stability. We believe that there is room for further improvement based on this class of complexes. For example, improvement of the chemical stability, as well as fine tuning of the emission efficiency and color hue may be achieved by systematically introducing the rigid and bulky or even the electron-donating/-withdrawing substituents to the chelating ligands. Work focusing on these issues is currently in progress.

\section{Experimental Section}

The iridium complex $\left[\{(\operatorname{cod}) \operatorname{Ir}(\mu-\mathrm{Cl})\}_{2}\right]$ was prepared by using cyclooctadiene and $\mathrm{IrCl}_{3} \cdot n \mathrm{H}_{2} \mathrm{O}$ in a $2: 1$ mixture of ethanol and water, ${ }^{[21]}$ and the pyridyl pyrazole (or triazole) ligands were prepared by using literature methods. ${ }^{[22]}$ All manipulations were performed under $\mathrm{N}_{2}$ atmosphere by using the standard Schlenk technique. Mass spectra were obtained by using a JEOL SX-102A instrument operating in either the electron impact (EI) or fast atom bombardment (FAB) mode. ${ }^{1} \mathrm{H}$ and ${ }^{13} \mathrm{C}$ NMR spectra were recorded on a Varian Mercury-400 instrument and elemental analysis was carried out by using a Heraeus CHN-O Rapid Elemental Analyzer.

Spectroscopic measurements: Steady-state absorption and emission spectra were recorded by using a Hitachi (U-3310) spectrophotometer and an Edinburgh (FS920) fluorimeter, respectively. Both the wavelength-dependent excitation and emission response of the fluorimeter had been calibrated. An integrating sphere (Labsphere) was applied to measure the quantum yield in the solid state, in which the solid sample film was prepared by using the spin-coating method and was excited by a $514 \mathrm{~nm} \mathrm{Ar}^{+}$ laser line. The resulting luminescence was channeled to an intensified charge-coupled detector for subsequent quantum-yield analyses. To obtain the PL quantum yield in the solid state, the emission was collected by using the integrating sphere, and the quantum yield was calculated according to a reported method. ${ }^{[23]}$

Lifetime studies were performed with an Edinburgh FL 900 photoncounting system by using a hydrogen-filled or a nitrogen lamp as the excitation source. Data were analyzed by using the nonlinear least-squares procedure in combination with an iterative convolution method. The emission decays were analyzed by the sum of exponential functions, which allows partial removal of the instrument time-broadening and con- 
sequently renders a temporal resolution of about 200 ps. Dichloromethane $(\mathrm{DCM})$ was used as a reference, assuming a quantum yield $\Phi_{\mathrm{f}}=$ $0.44,{ }^{[24]}$ to determine fluorescence quantum yields of the studied compounds in solution. Solution samples were degassed by three freezepump-thaw cycles. The resulting luminescence was acquired by an intensified charge-coupled detector.

Preparation of [(cod) $\operatorname{Ir}(\mathbf{f p p z})]$ (1): A $50-\mathrm{mL}$ reaction flask was charged with (fppz)H (31 mg, $0.16 \mathrm{mmol}), \mathrm{NaH}(5.4 \mathrm{mg}, 0.22 \mathrm{mmol})$, and anhydrous THF (30 mL). The mixture was stirred for $20 \mathrm{~min}$, until the $\mathrm{H}_{2}$ evolution ceased, and the solution was filtered under $\mathrm{N}_{2}$ to remove the unreacted $\mathrm{NaH}$. The filtrate was transferred to a second reaction flask charged with $\left[\{(\operatorname{cod}) \operatorname{Ir}(\mu-\mathrm{Cl})\}_{2}\right](50 \mathrm{mg}, 0.075 \mathrm{mmol})$, and the color immediately turned from brown to dark red. After stirring for $15 \mathrm{~min}$, the solution was filtered and the filtrate was evaporated to dryness. This crude product was purified by recrystallization in toluene at $-20^{\circ} \mathrm{C}$ to give dark red crystals ( $48 \mathrm{mg}, 0.092 \mathrm{mmol}, 62 \%$ ). The related $\mathrm{Ir}^{\mathrm{I}}$ complexes 2 4 were prepared by using similar procedures.

Complex 1: ${ }^{1} \mathrm{H}$ NMR $\left(400 \mathrm{MHz},\left[\mathrm{D}_{6}\right]\right.$ benzene, $25^{\circ} \mathrm{C}$, TMS): $\delta=7.03$ (d, $J$ $(\mathrm{H}, \mathrm{H})=6.0 \mathrm{~Hz}, 1 \mathrm{H}), 6.63(\mathrm{dt}, J(\mathrm{H}, \mathrm{H})=1.2,7.6 \mathrm{~Hz}, 1 \mathrm{H}), 6.52(\mathrm{~d}, J-$ $(\mathrm{H}, \mathrm{H})=8.4 \mathrm{~Hz}, 1 \mathrm{H}), 6.48(\mathrm{~s}, 1 \mathrm{H} ; \mathrm{CH}), 5.98(\mathrm{ddd}, J(\mathrm{H}, \mathrm{H})=7.6 \mathrm{~Hz}$, $5.6 \mathrm{~Hz}, 1.2 \mathrm{~Hz}, 1 \mathrm{H}), 5.28-5.14(\mathrm{~m}, 2 \mathrm{H}), 3.47-3.37(\mathrm{~m}, 2 \mathrm{H}), 2.24-2.08(\mathrm{~m}$, $4 \mathrm{H}), 1.72-1.58 \mathrm{ppm}(\mathrm{m}, 4 \mathrm{H})$; MS (FAB, $\left.{ }^{193} \mathrm{Ir}\right): \mathrm{m} / \mathrm{z}: 513\left[\mathrm{M}^{+}\right], 405\left[\mathrm{M}^{+}\right.$ -cod]; elemental analysis calcd (\%) for $\mathrm{C}_{17} \mathrm{H}_{17} \mathrm{~F}_{3} \mathrm{IrN}_{3}$ : C 39.84, H 3.34, N 8.20; found: C 40.20, H 3.73, N 8.17 .

Complex 2: ${ }^{1} \mathrm{H}$ NMR $\left(400 \mathrm{MHz},\left[\mathrm{D}_{6}\right]\right.$ benzene, $25^{\circ} \mathrm{C}$, TMS $): \delta=7.12(\mathrm{~d}, J-$ $(\mathrm{H}, \mathrm{H})=6.0 \mathrm{~Hz}, 1 \mathrm{H}), 6.75(\mathrm{~d}, J(\mathrm{H}, \mathrm{H})=8.0 \mathrm{~Hz}, 1 \mathrm{H}), 6.68(\mathrm{t}, J(\mathrm{H}, \mathrm{H})=$ $7.6 \mathrm{~Hz}, 1 \mathrm{H}), 6.27(\mathrm{~s}, 1 \mathrm{H}), 5.98(\mathrm{t}, J(\mathrm{H}, \mathrm{H})=6.4 \mathrm{~Hz}, 1 \mathrm{H}), 5.42-5.28(\mathrm{~m}$, 2H), 3.46-3.36 (m, 2H), 2.34-2.14 (m, 4H), 1.82-1.64 (m, 4H), $1.61 \mathrm{ppm}$ (s, 9H; CH); MS (FAB, $\left.{ }^{193} \mathrm{Ir}\right): m / z: 501\left[M^{+}\right], 393\left[M^{+}-\mathrm{cod}\right]$; elemental analysis calcd (\%) for $\mathrm{C}_{20} \mathrm{H}_{26} \mathrm{IrN}_{3}$ : C 47.98, H 5.23, N 8.39; found: C 47.41, H 5.34, N 8.18.

Complex 3: ${ }^{1} \mathrm{H}$ NMR $\left(400 \mathrm{MHz},\left[\mathrm{D}_{6}\right]\right.$ benzene, $25^{\circ} \mathrm{C}$, TMS $): \delta=7.50(\mathrm{~d}, J$ $(\mathrm{H}, \mathrm{H})=7.6 \mathrm{~Hz}, 1 \mathrm{H}), 6.90(\mathrm{~d}, J(\mathrm{H}, \mathrm{H})=6.0 \mathrm{~Hz}, 1 \mathrm{H}), 6.60(\mathrm{dt}, J(\mathrm{H}, \mathrm{H})=$ $1.2,7.6 \mathrm{~Hz}, 1 \mathrm{H}), 6.01(\mathrm{ddd}, J(\mathrm{H}, \mathrm{H})=1.2,5.6,7.6 \mathrm{~Hz}, 1 \mathrm{H}), 5.09-4.96(\mathrm{~m}$, 2 H), 3.47-3.30 (m, 2H), 2.18-2.00 (m, 4H), 1.67-1.48 ppm (m, 4H); MS (FAB, $\left.{ }^{193} \mathrm{Ir}\right): m / z: 514\left[\mathrm{M}^{+}\right], 406\left[\mathrm{M}^{+}-\mathrm{cod}\right]$; elemental analysis calcd (\%) for $\mathrm{C}_{16} \mathrm{H}_{16} \mathrm{~F}_{3} \mathrm{IrN}_{4}$ : C 37.42, H 3.14, N 10.91; found: C 37.23, H 3.56, N 10.71

Complex 4: ${ }^{1} \mathrm{H}$ NMR (400 MHz, $\left[\mathrm{D}_{6}\right]$ benzene, $\left.25^{\circ} \mathrm{C}\right): \delta=7.69(\mathrm{~d}, J$ $(\mathrm{H}, \mathrm{H})=7.6 \mathrm{~Hz}, 1 \mathrm{H}$; TMS $), 7.00(\mathrm{~d}, J(\mathrm{H}, \mathrm{H})=5.2 \mathrm{~Hz}, 1 \mathrm{H}), 6.61(\mathrm{dt}, J-$ $(\mathrm{H}, \mathrm{H})=1.2,8.0 \mathrm{~Hz}, 1 \mathrm{H}), 5.96(\mathrm{ddd}, J(\mathrm{H}, \mathrm{H})=1.6,5.6,7.2 \mathrm{~Hz}, 1 \mathrm{H}), 5.37-$ $5.30(\mathrm{~m}, 2 \mathrm{H}), 3.48-3.36(\mathrm{~m}, 2 \mathrm{H}), 2.27-2.12(\mathrm{~m}, 4 \mathrm{H}), 1.77(\mathrm{~s}, 9 \mathrm{H}), 1.72$ $1.56 \mathrm{ppm}(\mathrm{m}, 4 \mathrm{H})$; MS (FAB, $\left.{ }^{193} \mathrm{Ir}\right): \mathrm{m} / z: 502\left[\mathrm{M}^{+}\right], 394\left[\mathrm{M}^{+}-\mathrm{cod}\right]$; elemental analysis calcd (\%) for $\mathrm{C}_{19} \mathrm{H}_{25} \mathrm{IrN}_{4}$ : C 45.49, $\mathrm{H} 5.02, \mathrm{~N} 11.17$; found: C 45.54, H 5.24, N 10.80

Selected crystal data for complex 3: $\mathrm{C}_{16} \mathrm{H}_{16} \mathrm{~F}_{3} \mathrm{IrN}_{4}, M_{\mathrm{w}}=513.53$, triclinic, space group $P \overline{1}, \quad a=7.1616(2), \quad b=10.9549(3), \quad c=11.5488(3) \AA, \quad \alpha=$ 107.909(1), $\beta=103.474(1), \gamma=107.994(1)^{\circ}, V=764.24(4) \AA^{3}, Z=2, \rho_{\text {calcd }}=$ $2.232 \mathrm{~g} \mathrm{~cm}^{-1}, F(000)=488$, crystal size $0.25 \times 0.05 \times 0.02 \mathrm{~mm}^{3}, \lambda\left(\mathrm{Mo}_{\mathrm{K} \alpha}\right)=$ $0.7107 \AA, T=295 \mathrm{~K}, \mu=8.774 \mathrm{~mm}^{-1}, 12855$ reflections collected, 2687 with $R$ (int $)=0.0400$, final $w R_{2}($ all data $)=0.1454 . \quad R_{1}[I>2 \sigma(I)]=0.0508$. CCDC-624072 contains the supplementary crystallographic data for this paper. These data can be obtained free of charge from The Cambridge Crystallographic Data Centre via www.ccdc.cam.ac.uk/data_request/cif.

Synthesis of 1-(5-methyl-1H-pyrrol-2-yl)isoquinoline: 1-(5-Methyl- $1 \mathrm{H}$ pyrrol-2-yl)isoquinoline (mpiqH) was prepared from 1-methyl isoquinoline by using the established procedure described in reference [25]. ${ }^{1} \mathrm{H}$ NMR $\left(400 \mathrm{MHz},[\mathrm{D}]\right.$ chloroform, $25^{\circ} \mathrm{C}$, TMS): $\delta=10.52$ (brs, $1 \mathrm{H}$; $\mathrm{NH}), 8.74(\mathrm{~d}, J(\mathrm{H}, \mathrm{H})=8.4 \mathrm{~Hz}, 1 \mathrm{H}), 8.38(\mathrm{~d}, J(\mathrm{H}, \mathrm{H})=6.0 \mathrm{~Hz}, 1 \mathrm{H}), 7.76$ $(\mathrm{d}, J(\mathrm{H}, \mathrm{H})=8.0 \mathrm{~Hz}, 1 \mathrm{H}), 7.67-7.56(\mathrm{~m}, 2 \mathrm{H}), 7.40(\mathrm{~d}, J(\mathrm{H}, \mathrm{H})=8.4 \mathrm{~Hz}$ $1 \mathrm{H}), 6.93(\mathrm{~d}, J(\mathrm{H}, \mathrm{H})=3.2 \mathrm{~Hz}, 1 \mathrm{H}), 6.12(\mathrm{~d}, J(\mathrm{H}, \mathrm{H})=2.8 \mathrm{~Hz}, 1 \mathrm{H})$, 2.34 ppm (s, 3H); MS (EI): $m / z: 208\left[M^{+}\right]$; elemental analysis calcd (\%) for $\mathrm{C}_{14} \mathrm{H}_{12} \mathrm{~N}_{2}$ : C 80.74, H 5.81, N 13.45; found: C 80.89, H 5.71, N 13.52. Preparation of $\left[(\mathbf{t p y})_{2} \mathbf{I r}(\mathbf{m p i q})\right] \mathbf{~ ( 5 )}$ : A mixture of $\left[\{(\mathrm{tpy}) \mathrm{IrCl}\}_{2}\right](180 \mathrm{mg}$, $0.16 \mathrm{mmol}), \quad 1-(5$-methyl-1H-pyrrol-2-yl)isoquinoline $(\mathrm{mpiqH}, \quad 80 \mathrm{mg}$, $0.38 \mathrm{mmol})$ and $\mathrm{Na}_{2} \mathrm{CO}_{3}(168 \mathrm{mg}, 1.59 \mathrm{mmol})$ in 2-ethoxyethanol $(20 \mathrm{~mL})$ was refluxed for $4 \mathrm{~h}$. An excess of water was added after cooling of the solution to room temperature. The precipitate was collected by filtration and washed with diethyl ether $(10 \mathrm{~mL})$. Finally, this precipitate was purified by silica gel column chromatography by eluting with $\mathrm{CH}_{2} \mathrm{Cl}_{2}$ solvent. Yellow crystals of [(tpy) $\operatorname{Ir}_{2}$ (mpiq)] (5) were obtained by diffusing methanol into a saturated solution of $\mathrm{CH}_{2} \mathrm{Cl}_{2}(154 \mathrm{mg}, 0.21 \mathrm{mmol}, 65 \%)$ at room temperature. ${ }^{1} \mathrm{H}$ NMR $\left(400 \mathrm{MHz},\left[\mathrm{D}_{6}\right.\right.$ ]acetone, $\left.25^{\circ} \mathrm{C}, \mathrm{TMS}\right): \delta=$ $8.93(\mathrm{~d}, J(\mathrm{H}, \mathrm{H})=10.0 \mathrm{~Hz}, 1 \mathrm{H}), 7.95(\mathrm{~d}, J(\mathrm{H}, \mathrm{H})=8.0 \mathrm{~Hz}, 1 \mathrm{H}), 7.91(\mathrm{~d}, J-$ $(\mathrm{H}, \mathrm{H})=8.0 \mathrm{~Hz}, 1 \mathrm{H}), 7.81(\mathrm{dd}, J(\mathrm{H}, \mathrm{H})=6.8,1.6 \mathrm{~Hz}, 1 \mathrm{H}), 7.67-7.59(\mathrm{~m}$, $8 \mathrm{H}), 7.46(\mathrm{~d}, J(\mathrm{H}, \mathrm{H})=6.0 \mathrm{~Hz}, 1 \mathrm{H}), 7.26(\mathrm{~d}, J(\mathrm{H}, \mathrm{H})=3.6 \mathrm{~Hz}, 1 \mathrm{H}), 6.92-$ $6.85(\mathrm{~m}, 3 \mathrm{H}), 6.71(\mathrm{dd}, J(\mathrm{H}, \mathrm{H})=7.8,1.6 \mathrm{~Hz}, 1 \mathrm{H}), 6.64(\mathrm{dd}, J(\mathrm{H}, \mathrm{H})=7.8$ $1.2 \mathrm{~Hz}, 1 \mathrm{H}), 6.18(\mathrm{~s}, 2 \mathrm{H}), 6.01(\mathrm{~d}, J(\mathrm{H}, \mathrm{H})=3.6 \mathrm{~Hz}, 1 \mathrm{H}), 2.05(\mathrm{~s}, 3 \mathrm{H})$, $1.99(\mathrm{~s}, 3 \mathrm{H}), 1.58 \mathrm{ppm}(\mathrm{s}, 3 \mathrm{H})$; MS (FAB): $\mathrm{m} / z$ : $737\left[\mathrm{M}^{+}\right]$; elemental analysis calcd $(\%)$ for $\mathrm{C}_{38} \mathrm{H}_{31} \mathrm{IrN}_{4}$ : $\mathrm{C} 62.02, \mathrm{H} 4.25, \mathrm{~N} 7.61$; found: $\mathrm{C}$ $62.18, \mathrm{H} 4.11$, N 7.57

Computational methodology: Calculations on the electronic ground state of complexes 1-3 were carried out by using B3LYP density functional theory. ${ }^{[26,27]}$ A "double- $\zeta$ " quality basis set consisting of the Hay and Wadt effective core potentials (LANL2DZ) ${ }^{[28]}$ was employed for the Ir atom and $6-31 \mathrm{G}^{*}$ basis $^{[29]}$ for $\mathrm{H}, \mathrm{C}, \mathrm{N}$, and $\mathrm{F}$ atoms. A relativistic effective core potential $(\mathrm{ECP})$ replaced the inner core electrons of $\mathrm{Ir}^{\mathrm{I}}$, leaving the outer core $\left(5 s^{2} 5 p^{6}\right)$ electrons and the $5 d^{8}$ valence electrons. Time-dependent DFT (TDDFT) calculations ${ }^{[30]}$ by using the B3LYP functional were then performed based on the structural optimized geometries. Typically, the lowest ten triplet and ten singlet roots of the nonhermitian eigenvalue equations were obtained to determine the vertical excitation energies. Oscillator strengths $(f)$ were deduced from the dipole transition matrix elements (for singlet states only). The ground-state B3LYP and excitedstate TDDFT calculations were carried out by using Gaussian 03, as described in our previous publications. ${ }^{[31]}$ The UV/Vis spectrum was convoluted with Gaussian curves of full-width at half-maximum (fwhm) of $3000 \mathrm{~cm}^{-1}$ by using SWizard $4.14 .^{[32]}$

\section{Acknowledgements}

We thank the support from the following research grants (NSC 912119M-002-016) and (94-EC-17A-08-S1-042).

[1] a) M. A. Baldo, D. F. O'Brien, Y. You, A. Shoustikov, S. Sibley, M. E. Thompson, S. R. Forrest, Nature 1998, 395, 151; b) E. Holder, B. M. W. Langeveld, U. S. Schubert, Adv. Mater. 2005, 17, 1109; c) R. C. Evans, P. Douglas, C. J. Winscom, Coord. Chem. Rev. 2006, 250, 2093.

[2] a) P.-T. Chou, Y. Chi, Eur. J. Inorg. Chem. 2006, 3319; b) S. Tokito, T. Iijima, T. Tsuzuki, F. Sato, Appl. Phys. Lett. 2003, 83, 2459; c) S. C. Lo, E. B. Namdas, P. L. Burn, I. D. W. Samuel, Macromolecules 2003, 36, 9721; d) R. C. Kwong, M. R. Nugent, L. Michalski, T. Ngo, K. Rajan, Y.-J. Tung, M. S. Weaver, T. X. Zhou, M. Hack, M. E. Thompson, S. R. Forrest, J. J. Brown, Appl. Phys. Lett. 2002, 81, 162; e) G. He, S.-C. Chang, F.-C. Chen, Y. Li, Y. Yang, Appl. Phys. Lett. 2002, 81, 1509; f) C.-L. Lee, K. B. Lee, J.-J. Kim, Appl. Phys. Lett. 2000, 77, 2280

[3] a) K. Koike, N. Okoshi, H. Hori, K. Takeuchi, O. Ishitani, H. Tsubaki, I. P. Clark, M. W. George, F. P. A. Johnson, J. J. Turner, J. Am Chem. Soc. 2002, 124, 11448; b) J.-K. Yu, Y.-H. Hu, Y.-M. Cheng, P.-T. Chou, S.-M. Peng, G.-H. Lee, A. J. Carty, Y.-L. Tung, S.-W. Lee, Y. Chi, C.-S. Liu, Chem. Eur. J. 2004, 10, 6255; c) Y.-L. Tung, S.-W. Lee, Y. Chi, L.-S. Chen, C.-F. Shu, F.-I. Wu, A. J. Carty, P.-T. Chou, S.-M. Peng, G.-H. Lee, Adv. Mater. 2005, 17, 1059.

[4] a) B.-H. Xia, H.-X. Zhang, C.-M. Che, K.-H. Leung, D. L. Phillips, N. Zhu, Z.-Y. Zhou, J. Am. Chem. Soc. 2003, 125, 10362; b) W. Lu, M. C. W. Chan, N. Zhu, C.-M. Che, C. Li, Z. Hui, J. Am. Chem. Soc. 2004, 126, 7639; c) B. Ma, J. Li, P. I. Djurovich, M. Yousufuddin, R. Bau, M. E. Thompson, J. Am. Chem. Soc. 2005, 127, 28

[5] a) T. J. Wadas, S. Chakraborty, R. J. Lachicotte, Q.-M. Wang, R. Eisenberg, Inorg. Chem. 2005, 44, 2628; b) F. Guo, W. Sun, Y. Liu, K. Schanze, Inorg. Chem. 2005, 44, 4055; c) A. Diez, J. Fornies, A. 
Garcia, E. Lalinde, M. T. Moreno, Inorg. Chem. 2005, 44, 2443; d) C.-H. Tao, N. Zhu, V. W.-W. Yam, Chem. Eur. J. 2005, 11, 1647; e) H. Jude, J. A. Krause Bauer, W. B. Connick, Inorg. Chem. 2005, 44, 1211; f) S. J. Farley, D. L. Rochester, A. L. Thompson, J. A. K. Howard, J. A. G. Williams, Inorg. Chem. 2005, 44, 9690.

[6] a) S.-W. Lai, C.-M. Che, Top. Curr. Chem. 2004, 241, 27; b) A. S. Ionkin, W. J. Marshall, Y. Wang, Organometallics 2005, 24, 619; c) P. T. Furuta, L. Deng, S. Garon, M. E. Thompson, J. M. J. Frechet, J. Am. Chem. Soc. 2004, 126, 15388; d) W. Sotoyama, T. Satoh, N. Sawatari, H. Inoue, Appl. Phys. Lett. 2005, 86, 153505.

[7] a) R. C. Kwong, S. Sibley, T. Dubovoy, M. Baldo, S. R. Forrest, M. E. Thompson, Chem. Mater. 1999, 11, 3709; b) C.-M. Che, Y.-J. Hou, M. C. W. Chan, J. Guo, Y. Liu, Y. Wang, J. Mater. Chem. 2003, 13, 1362; c) Q. Hou, Y. Zhang, F. Li, J. Peng, Y. Cao, Organometallics 2005, 24, 4509; d) M. Ikai, F. Ishikawa, N. Aratani, A. Osuka, S. Kawabata, T. Kajioka, H. Takeuchi, H. Fujikawa, Y. Taga, Adv. Funct. Mater. 2006, 16, 515 .

[8] a) J. Brooks, Y. Babayan, S. Lamansky, P. I. Djurovich, I. Tsyba, R. Bau, M. E. Thompson, Inorg. Chem. 2002, 41, 3055; b) Y.-Y. Lin, S.C. Chan, M. C. W. Chan, Y.-J. Hou, N. Zhu, C.-M. Che, Y. Liu, Y. Wang, Chem. Eur. J. 2003, 9, 1263; c) C.-M. Che, S.-C. Chan, H.-F. Xiang, M. C. W. Chan, Y. Liu, Y. Wang, Chem. Commun. 2004, 1484; d) C.-C. Kwok, H. M. Y. Ngai, S.-C. Chan, I. H. T. Sham, C.M. Che, N. Zhu, Inorg. Chem. 2005, 44, 4442; e) W.-Y. Wong, Z. He, S.-K. So, K.-L. Tong, Z. Lin, Organometallics 2005, 24, 4079; f) F. Galbrecht, X. H. Yang, B. S. Nehls, D. Neher, T. Farrell, U. Scherf, Chem. Commun. 2005, 2378.

[9] a) H.-F. Xiang, S.-C. Chan, K. K.-Y. Wu, C.-M. Che, P. T. Lai, Chem. Commun. 2005, 1408; b) J. Kavitha, S.-Y. Chang, Y. Chi, J.-K. Yu, Y.-H. Hu, P.-T. Chou, S.-M. Peng, G.-H. Lee, Y.-T. Tao, C.-H. Chien, A. J. Carty, Adv. Funct. Mater. 2005, 15, 223; c) S.-Y. Chang, J. Kavitha, S.-W. Li, C.-S. Hsu, Y. Chi, Y.-S. Yeh, P.-T. Chou, G.-H. Lee, A. J. Carty, Y.-T. Tao, C.-H. Chien, Inorg. Chem. 2006, 45, 137.

[10] a) W. A. Fordyce, G. A. Crosby, Inorg. Chem. 1982, 21, 1455; b) M. I. S. Kenney, J. W. Kenney III, G. A. Crosby, Organometallics 1986, 5, 230; c) H. Kunkely, A. Vogler, Inorg. Chem. Commun. 2005, $8,119$.

[11] C.-C. Cheng, W.-S. Yu, P.-T. Chou, S.-M. Peng, G.-H. Lee, P.-C. Wu, Y.-H. Song, Y. Chi, Chem. Commun. 2003, 2628.

[12] a) Y.-L. Tung, P.-C. Wu, C.-S. Liu, Y. Chi, J.-K. Yu, Y.-H. Hu, P.-T. Chou, S.-M. Peng, G.-H. Lee, Y.-T. Tao, A. J. Carty, C.-F. Shu, F.-I. Wu, Organometallics 2004, 23, 3745; b) Y.-H. Song, S.-J. Yeh, C.-T. Chen, Y. Chi, C.-S. Liu, J.-K. Yu, Y.-H. Hu, P.-T. Chou, S.-M. Peng, G.-H. Lee, Adv. Funct. Mater. 2004, 14, 1221.

[13] a) C.-H. Yang, S.-W. Li, Y. Chi, Y.-M. Cheng, Y.-S. Yeh, P.-T. Chou, G.-H. Lee, C.-H. Wang, C.-F. Shu, Inorg. Chem. 2005, 44, 7770; b) C. S. K. Mak, A. Hayer, S. I. Pascu, S. E. Watkins, A. B. Holmes, A. Koehler, R. H. Friend, Chem. Commun. 2005, 4708.

[14] P.-C. Wu, J.-K. Yu, Y.-H. Song, Y. Chi, P.-T. Chou, S.-M. Peng, G.-H. Lee, Organometallics 2003, 22, 4938.
[15] J. DePriest, G. Y. Zheng, N. Goswami, D. M. Eichhorn, C. Woods, D. P. Rillema, Inorg. Chem. 2000, 39, 1955.

[16] A. Tsuboyama, H. Iwawaki, M. Furugori, T. Mukaide, J. Kamatani, S. Igawa, T. Moriyama, S. Miura, T. Takiguchi, S. Okada, M. Hoshino, K. Ueno, J. Am. Chem. Soc. 2003, 125, 12971.

[17] C. Adachi, M. A. Baldo, S. R. Forrest, M. E. Thompson, Appl. Phys. Lett. 2000, 77, 904.

[18] V. Adamovich, J. Brooks, A. Tamayo, A. M. Alexander, P. Djurovich, B. W. D'Andrade, C. Adachi, S. R. Forrest, M. E. Thompson, New J. Chem. 2002, 26, 1171.

[19] a) F.-M. Hwang, H.-Y. Chen, P.-S. Chen, C.-S. Liu, Y. Chi, C.-F. Shu, F.-I. Wu, P.-T. Chou, S.-M. Peng, G.-H. Lee, Inorg. Chem. 2005, 44 1344; b) Y.-H. Niu, B. Chen, S. Liu, H. Yip, J. Bardecker, A. K.-Y. Jen, J. Kavitha, Y. Chi, C.-F. Shu, Y.-H. Tseng, C.-H. Chien, Appl. Phys. Lett. 2004, 85, 1619.

[20] a) H. Yersin, J. Strasser, Coord. Chem. Rev. 2000, 208, 331; b) H. Yersin, D. Donges, Top. Curr. Chem. 2001, 214, 81; c) H. Yersin, Top. Curr. Chem. 2004, 241, 1.

[21] J. L. Herde, J. C. Lambert, C. V. Senoff, Inorg. Synth. 1974, 15, 18.

[22] a) W. R. Thiel, J. Eppinger, Chem. Eur. J. 1997, 3, 696; b) S. P. Singh, D. Kumar, B. G. Jones, M. D. Threadgill, J. Fluorine Chem. 1999, 94, 199.

[23] J. C. de Mello, H. F. Wittmann, R. H. Friend, Adv. Mater. 1997, 9, 230.

[24] J. M. Darke, M. L. Lesiecki, D. M. Camaioni, Chem. Phys. Lett. 1985, 113, 530.

[25] H.-Y. Chen, Y. Chi, C.-S. Liu, J.-K. Yu, Y.-M. Cheng, K.-S. Chen, P.T. Chou, S.-M. Peng, G.-H. Lee, A. J. Carty, S.-J. Yeh, C.-T. Chen, Adv. Funct. Mater. 2005, 15, 567.

[26] C. Lee, W. Yang, R. G. Parr, Phys. Rev. B 1988, 37, 785.

[27] A. D. Becke, J. Chem. Phys. 1993, 98, 5648.

[28] a) P. J. Hay, W. R. Wadt, J. Chem. Phys. 1985, 82, 270; b) W. R Wadt, P. J. Hay, J. Chem. Phys. 1985, 82, 284; c) P. J. Hay, W. R. Wadt, J. Chem. Phys. 1985, 82, 299.

[29] P. C. Hariharan, A. Pople, J. Mol. Phys. 1974, 27, 209.

[30] a) C. Jamorski, M. E. Casida, D. R. Salahub, J. Chem. Phys. 1996, 104, 5134; b) M. Petersilka, U. J. Grossmann, E. K. U. Gross, Phys. Rev. Lett. 1996, 76, 1212; c) R. Bauernschmitt, R. Ahlrichs, F. H. Hennrich, M. M. Kappes, J. Am. Chem. Soc. 1998, 120, 5052; d) M. E. Casida, J. Chem. Phys. 1998, 108, 4439; e) R. E. Stratmann, G. E. Scuseria, M. J. Frisch, J. Chem. Phys. 1998, 109, 8218.

[31] Y.-L. Chen, S.-W. Li, Y. Chi, Y.-M. Cheng, S.-C. Pu, Y.-S. Yeh, P.-T. Chou, ChemPhysChem 2005, 6, 2012.

[32] S. I. Gorelsky, SWizard program, http://www.sg-chem.net/.

Received: July 17, 2006 Revised: October 18, 2006 Published online: December 15, 2006 